\title{
Aktivitas Antibakteri Ekstrak Etanol Daun Bandotan (Ageratum Conyzoides L.) Terhadap Bakteri Streptococcus Pyogenes
}

\author{
Jovita Almira, Yusransyah, Banu Kuncoro, Rahmawida Putri*, Nuriyatul Fhatonah \\ Program Studi Farmasi, Sekolah Tinggi Farmasi Muhammadiyah Tangerang, Banten, Indonesia \\ Email: rahmawidaputri0@gmail.com
}

\begin{abstract}
Abstrak-Pengobatan penyakit infeksi bakteri menggunakan antibiotik semi sintetik dapat menimbulkan resistensi, sehingga untuk mengatasinya diperlukan pencarian bahan obat alami dari tanaman, salah satunya yaitu ekstrak daun bandotan (Ageratum conyzoides L.) . Penelitian ini bertujuan untuk mengidentifikasi golongan senyawa kimia yang terkandung dalam daun bandotan dan mengetahui aktivitasnya sebagai antibakteri terhadap Streptococcus pyogenes dan Pseudomonas aeruginosa. Daun bandotan diekstraksi secara maserasi menggunakan pelarut etanol 96\%. Ekstrak diuji aktivitas antibakteri menggunakan metode sumuran dan diukur zona bening yang terbentuk menggunakan jangka sorong dan dilakukan triplo. Hasil identifikasi senyawa metabolit sekunder daun bandotan menunjukkan adanya senyawa golongan alkaloid, saponin, tanin, fenolik, flavonoid, triterpenoid, steroid, glikosida. Berdasarkan uji aktivitas antibakteri terhadap Streptococcus pyogenes dengan konsentrasi 100\%, 50\%, 25\%, 12,5\%, 6,25\% menunjukkan adanya zona bening pada konsentrasi berturut-turut dengan rata-rata sebesar $14,52 \mathrm{~mm} ; 13,87 \mathrm{~mm} ; 13,38 \mathrm{~mm} ; 12,38 \mathrm{~mm} ; 11,75 \mathrm{~mm} ; 15,33 \mathrm{~mm}$.
\end{abstract}

Kata Kunci: Daun Bandotan (Ageratum conyzoides L.); Antibakteri; Streptococcus Pyogenes; Pseudomonas Aeruginosa

\begin{abstract}
The treatment of bacterial infectious diseases using a semi synthetic antibiotic can lead to resistance, so that the search is necessary to overcome it the ingredients of natural medicine from plants, one of them namely bandotan leaf extract (Ageratum conyzoides 1.). This research aims to identify the chemical compounds contained in leaf bandotan and knowing his activity as antibacterial against Pseudomonas aeruginosa and s. pyogenes. The leaves are extracted in bandotan maceration using solvent ethanol $96 \%$. The extract was tested using the method of antibacterial activity of sumuran and clear zones are measured that is formed using a caliper and triplo. The results of the identification of a compound leaf bandotan secondary metabolite showed a group of compounds alkaloids, saponins, tannins, flavonoids, phenolic, triterpenoid glycosides, steroids. Based on a test of antibacterial activity against s. pyogenes with the concentration of $100 \%, 50 \%, 25 \%, 12.5 \%, 6.25 \%$ showed a clear zone on the concentration in a row with an average of $14.52 \mathrm{~mm} ; 13.87 \mathrm{~mm} ; 13.38 \mathrm{~mm} ; 12.38 \mathrm{~mm} ; 11.75 \mathrm{~mm} ; 15.33 \mathrm{~mm}$. While testing the antibacterial activity against Pseudomonas aeruginosa with the same concentrations did not show the presence of antibacterial activity of extracts of leaves of bandotan with no clear zone formation.
\end{abstract}

Keywords: Leaf Bandotan (Ageratum conyzoides L.); Antibacterial; Streptococcus Pyogenes; Pseudomonas Aeruginosa.

\section{PENDAHULUAN}

Penyakit infeksi merupakan jenis penyakit yang paling banyak diderita oleh penduduk di negara berkembang, termasuk Indonesia. Salah satu penyebab penyakit infeksi adalah bakteri. Bakteri merupakan mikroorganisme yang hanya dapat dilihat dengan bantuan mikroskop (Radji dan Manurung, 2011). Beberapa bakteri yang menyebabkan infeksi adalah Streptococcus pyogenes yang dapat menginfeksi berbagai bagian tubuh seperti faring dan kulit. Infeksi pada faring dapat menyebabkan terjadinya abses, sedangkan infeksi pada kulit dapat menyebabkan terjadinya impetigo (Brooks et al, 2013). Pseudomonas aeruginosa menyebabkan infeksi yang signifikan secara klinis seperti luka, infeksi luka bakar dan infeksi kuku (Hingkua, dkk. 2013). Pengobatan yang tidak tepat dengan obat sintetik dapat menyebabkan resistensi bakteri sehingga obat tidak mampu lagi memberikan efek yang seharusnya, dengan demikian dapat menimbulkan masalah baru. Hal ini berbeda jika pengobatan menggunakan obat herbal. Senyawa kimia yang terkandung didalamnya dapat berperan dalam memperbaiki sel-sel tubuh yang rusak. Di samping itu penggunaan obat herbal lebih aman dibanding obat sintetik (Sidoretno \& Rz. 2018; Lau, dkk. 2019).

Salah satu tanaman obat yang cukup dikenal di masyarakat adalah bandotan (Ageratum conyzoides, L.). Bandotan biasa tumbuh liar dan mudah didapat di Indonesia. Beberapa kegunaan dari tumbuhan ini adalah sebagai obat luka berdarah, bisul, borok dan eksim (Wijaya \& Ulfah, 2018; Mulyani, dkk. 2021). Tanaman bandotan mengandung senyawasenyawa metabolit sekunder seperti asam amino, minyak atsiri, kumarin, $\beta$-sitosterol, tanin, dan alkaloid (Munira, dkk. 2020; Safrida \& Rahmah, 2021). Tumbuhan bandotan merupakan salah satu tumbuhan yang diketahui secara empiris mempunyai khasiat sebagai bahan obat dan telah digunakan di beberapa daerah. Tumbuhan bandotan sejak dahulu telah digunakan secara luas dalam pengobatan tradisional oleh masyarakat, anatara lain untuk pengoabatan luka, gangguan pencernaan dan diare. Namun, selain itu juga digunakan sebagai pengobatan radang usus, radang ginjal atau radang saluran kemih dan penyakit yang disebabkan oleh infeksi bakteri contohnya seperti bakteri E.Coli, Sterptococcus. (Yasir \& Asnah, 2017).

Berdasarkan penelitian (Mengkido, dkk. 2019) tentang uji daya hambat ekstrak etanol daun bandotan terhadap pertumbuhan bakteri Streptococcus aureus mengandung senyawa antibiotik yang dapat mempengaruhi bakteri. Hal ini disebabkan daun bandotan mengandung senyawa yang dapat menghambat pertumbuhan bakteri yaitu pada kosentarsi $50 \%$ menghasilkan diameter zona hambat $22,0 \mathrm{~mm}$ dan pada kosentarsi $7,5 \%$ menghasilkan diameter zona hambat 9,0 mm. Sedangkan menurut penelitian (Laoli, 2018) Pada Uji Aktivitas Ekstrak Etanol Daun Bandotan Terahadap Bacteri Bacillus Substilis dan Proteus Vulgaris menunjukkan bahwa daun bandotan memberikan aktivitas sebagai antibakteri yang dapat menghambat pertumbuhan bakteri yaitu pada ekstrak etanol hasil diameter area jernih sebesar 14,28 mm untuk Bacillus substilis pada kosentrasi $80 \%$ dan pada Proteus Vulgaris memberikan diameter 14,41 mm pada kosentrasi $100 \%$. 


\section{Journal of Pharmaceutical and Health Research}

Vol 2, No 2, Juni 2021, pp. 28-33

ISSN 2721-0715 (media online)

DOI 10.47065/jharma.v2i2.841

Pengukuran zona hambat adalah penetuan dan pengukuran kepekaan suatu Safrida, dkk, bakteri terhadap suatu obat dimana kadar konsentrasi rendah masih menunjukkan zona hambat. Untuk pengukuran zona hambatan suatu obat atau bahan percobaan diukur dengan menggunakan mistar dalam $\mathrm{mm}$. Zona hambatan yang terjadi ditandai apabila disekitar obat atau bahan percobaan menunjukkan daerah jernih sebagai zona hambat (Sugara,dkk. 2016). Pengamatan dilakukan dengan cara mengukur zona bening yang terbentuk menggunakan jangka sorong, sehingga dapat disebut dengan zona hambat. Kategori zona hambat dapat diketahui pada tabel 1 dibawah ini

Tabel 1. Kategori Diameter Zona Hambat

\begin{tabular}{cc}
\hline Diameter & Kekuatan Daya Hambat \\
\hline$\leq 5 \mathrm{~mm}$ & Lemah \\
$6-10 \mathrm{~mm}$ & Sedang \\
$11-20 \mathrm{~mm}$ & Kuat \\
$\geq 21 \mathrm{~mm}$ & Sangat Kuat \\
\hline
\end{tabular}

\section{METODOLOGI PENELITIAN}

\subsection{Alat dan Bahan}

\subsubsection{Alat}

Botol kaca tertutup dan rotary evaporator. Alat yang digunakan untuk menganalisis adalah tabung reaksi, rak tabung reaksi, penjepit anatomis, pipet tetes, dan kertas pH. Alat untuk uji antibakteri lampu spiritus, LAF (Laminar Air Flow), ose, cawan petri, mikropipet, gelas objek, mikroskop dan inkubator.

\subsubsection{Bahan}

Etanol 96\% dan daun bandotan. Bahan yang digunakan untuk proses analisis ekstrak adalah ekstrak etanol 96\% daun bandotan, aquadest, kloroform, etanol, $\mathrm{FeCl} 31 \%$, serbuk $\mathrm{Mg}, \mathrm{HCl}, \mathrm{H} 2 \mathrm{SO} 42 \mathrm{M}$, meyer, dragendroff, wagner, Liebermann-Burchard. Bahan yang digunakan untuk uji antibakteri adalah antibiotik pembanding Kloramfenikol, media uji Mueller-Hinton Agar (MHA), $\mathrm{NaCl}$ 0,9\%, aquadest, bakteri Streptococcus pyogenes.

\subsection{Prosedur Penelitian}

\subsubsection{Determinasi Tumbuhan}

Determinasi dilakukan untuk memastikan kebenaran tanaman yang dipakai. Proses determinasi ini dilakukan di Herbarium Bogoriense, bidang Botani Pusat Penelitian dan Pengembangan Biologi (LIPI Cibinong) Jl. Raya Jakarta Bogor KM.46 Cibinong Bogor, 16911 Jawa Barat.

\subsubsection{Pembuatan Ekstrak}

Proses pembuatan ekstrak daun bandotan dilakukan di Balitro-Bogor. Pertama Ditimbang serbuk kering daun bandotan lalu dimaserasi dengan pelarut etanol sampai semua sampel terendam selama 3 hari sambil diaduk. Dilakukan 3 kali pengulangan kemudian saring dengan kertas Whatman, gabungkan filtrat. Selanjutnya ekstrak yang didapat akan di rotary evaporator guna menguapkan pelarutnya.

\subsubsection{Pengujian Parameter Ekstrak}

\section{a. Kadar Air}

Sampel dimasukkan dalam tabung bola (flask), kemudian dipanaskan. Air dan pelarut menguap, diembunkan dan jatuh pada tabung Aufhauser yang berskala. Air yang mempunyai berat jenis lebih besar berada dibagian bawah, sehingga jumlah air yang diuapkan dapat dilihat pada skala tabung Aufhauser.

\section{b. Kadar Abu}

Ekstrak etanol 96\% daun bandotan ditimbang sebanyak 1 gram, dimasukkan ke dalam krus silikat yang telah dipijarkan dan ditara, lalu ekstrak diratakan. Pijarkan perlahan-lahan hingga arang habis, dinginkan lalu timbang. Jika arang tidak menghilang, tambahkan air panas, kemudian saring menggunakan kertas saring bebas abu. Dipijarkan sisa kertas saring dalam krus yang sama. Filtrat dimasukkan dalam krus, diuapkan, lalu dipijarkan hingga bobot tetap dan ditimbang. Kadar abu dihitung terhadap berat ekstrak (Depkes RI, 2000 didalam Mentari, dkk. 2020)

\section{c. Sisa Pelarut}

Ekstrak ditimbang 5 gram, dilarutkan sampel $10 \mathrm{ml} \mathrm{H} 2 \mathrm{SO} 4$ 0,08 N, divotex, disentrifuge $13000 \mathrm{rpm}$ selama 10 menit, diinjek ke HPLC.

\subsubsection{Uji Skrining Fitokimia}

\section{a. Uji Saponin}




\title{
Journal of Pharmaceutical and Health Research
}

\author{
Vol 2, No 2, Juni 2021, pp. 28-33 \\ ISSN 2721-0715 (media online) \\ DOI 10.47065/jharma.v2i2.841
}

Sebanyak 1 gram ekstrak ditambah dengan $20 \mathrm{~mL}$ aquades, kemudian dipanaskan selama 5 menit. Larutan dituang kedalam tabung reaksi dalam keadaan panas. Larutan diambil sebanyak $10 \mathrm{~mL}$, kemudian dikocok kuat secara vertikal selama 10 detik. Adanya saponin ditandai dengan terbentuknya busa yang stabil setinggi 1-10 cm selama 10 menit dan tidak hilang pada saat ditambahkan dengan satu tetes $\mathrm{HCl}$ 2M (Arifin, dkk. 2019)

\section{b. Uji Flavonoid}

Ekstrak kental ditambah etanol kemudian ditambahkan 0,20 gram serbuk Mg dan 3 tetes HCl. Terbentuknya warna merah atau jingga pada lapisan etanol menunjukkan adanya senyawa flavonoid (Arifin, dkk. 2019).

\section{c. Uji Tanin}

Sebanyak $100 \mathrm{mg}$ ekstrak diencerkan dengan $100 \mathrm{~mL}$ air panas, didihkan selama 5 menit dan disaring. Sebagian filtrat yang diperoleh ditambahkan larutan $\mathrm{FeCl} 3$ 10\%. Terbentuknya warna hitam kehijauan menunjukkan adanya tanin (Arifin, dkk. 2019).

\section{d. Uji Polifenol}

Ekstrak kental ditambahkan aquades, selanjutnya ditambahkan $\mathrm{FeCl} 31 \%$ sebanyak 5 tetes dan diamati perubahan warna yang terjadi. Perubahan warna menjadi hijau biru hingga hitam menunjukkan adanya senyawa polifenol (Arifin, dkk. 2019).

\section{e. Uji Alkaloid}

0,5 gram sampel ditambah $1 \mathrm{ml} \mathrm{HCl} 2 \mathrm{~N}$ dan ditambah $9 \mathrm{ml}$ aquadest panas goyangkan sampai homogen diamkan selama 2 menit, kemudian saring filtratnya dibagi 2 ke dalam tabung : tabung 1 ditambah pereaksi bauchardat terbentuk endapan coklat-hitam menunjukkan adanya alkaloid. Tabung 2 ditambah pereaksi dragendrauf membentuk endapan coklat menunjukkan adanya alkaloid (Arifin, dkk. 2019).

\section{f. Uji Triterpenoid dan Steroid}

Filtrat yang dihasilkan dipindahkan kedalam pelat tetes dan dibiarkan sampai menguap pelarutnya. Kemudian kedalamnya ditambahkan pereaksi Liebermann-Burchard (1 tetes asam sulfat pekat dan 3 tetes asam asetat anhidrat). Uji positif jika timbul warna merah menandakan adanya triterpenoid, biru atau ungu menandakan adanya senyawa steroid (Arifin, dkk. 2019).

\section{g. Uji Glikosida}

Sampel sebanyak 3 gram dalam labu colf $50 \mathrm{ml}$ dicampur dengan $30 \mathrm{ml}$ (21 $\mathrm{ml}$ etanol dan $9 \mathrm{ml}$ air) dipanaskan hingga mendidih selama 10 menit. Sampel kemudian didinginkan dan disaring. Filtrat yang dihasilkan kemudian ditambahkan 2 $\mathrm{ml} \mathrm{Pb}$ asetat sebesar $5 \%$ dan isopropanol. Lapisan bawah dimasukkan ke dalam cawan pinggan penguap dan dipanaskan hingga 400C. Setelah cairan kental ditambah $2 \mathrm{ml}$ metanol ke dalam tabung reaksi menjadi 5 bagian. Tabung pertama diuapkan hingga kering dan ditambahkan dengan 10 tetes $\mathrm{H} 2 \mathrm{SO} 4$ dan $5 \mathrm{ml}$ asam asetat anhidrat. Bila terbentuk warna biru hijau, maka sampel tersebut mengandung glikosida. Tabung kedua diuapkan hingga kering dan ditambahkan $2 \mathrm{ml}$ air dan 5 tetes molish dan $2 \mathrm{ml} \mathrm{H} 2 \mathrm{SO} 4$. Bila terbentuk cincin ungu maka sampel positif mengandung glikosida. Tabung ketiga ditambah dengan $2.9 \mathrm{ml}$ metanol dan baljet. Bila terbentuk warna merah jingga, maka sampel positif mengandung glikosida jantung. Tabung keempat ditambah dengan $2 \mathrm{ml} \mathrm{KOH} 0.1 \mathrm{~N}$ dan $2 \mathrm{ml} \mathrm{Kadede}$. Bila terbentuk warna merah ungu, maka sampel positif mengandung glikosida jantung (Arifin, dkk. 2019)

\subsubsection{Inokulasi Bakteri}

Tambahkan $2 \mathrm{ml} \mathrm{NaCl}$ fisiologis ke dalam tabung reaksi berisi bakteri goyangkan hingga merata. Buatlah media Nutrien Broth sebanyak $20 \mathrm{ml}$ dan masukan kedalam erlenmeyer. Ambil bakteri menggunakan mikro pipet sebanyak $1 \mathrm{ml}$ dan masukkan kedalam erlenmeyer tersebut. Shaker erlenmeyer dengan kecepatan $150 \mathrm{rpm}$ selama \pm 18 jam. Pipet $1 \mathrm{ml}$ sampel bakteri dan masukkan kedalam tabung reaksi yang telah berisi $9 \mathrm{ml} \mathrm{NaCl}$ fisiologis $0,85 \%$ goyangkan hingga homogen (Pengenceran 10-1), lakukan pengenceran hingga tingkat 10-7. Pipet masing-masing 1 ml dari pengenceran 105 - 10-7 kedalam cawan petri steril secara duplo. Kedalam cawan petri tuangkan sebanyak $20 \mathrm{ml}$ media Nutrien Agar goyangkan hingga merata. Biarkan hingga campuran dalam cawan membeku, dan inkubasi pada suhu $\pm 360 \mathrm{C}$ selama 24 jam dengan posisi terbalik. Hitung dan catat pertumbuhan koloni pada setiap cawan petri yang mengandung 10-300 koloni.

\subsubsection{Uji Aktivitas Antibakteri}

Mueller-Hinton agar yang telah dicampurkan dengan bakteri uji dibuat lubang sebesar 6 mm dengan metode sumuran (pencetak lubang) kemudian masing-masing lubang diisi ekstrak daun bandotan dengan variasi konsentrasi 100\%, 50\%, $25 \%, 12,5 \%, 6,25 \%$ dengan volume penetesan $25 \mu \mathrm{l}$, lalu dibuat 2 buah kontrol yaitu DMSO 2\% dan Kloramfenikol dengan konsentrasi 1000 ppm untuk pengujian Streptococcus pyogenes dan 3000 ppm, lalu dibiarkan selama 15 menit, dan diinkubasi dalam inkubator pada temperature $35^{\circ} \mathrm{C}$ selama 18 jam. Hasil inkubasi kemudian dilihat dan daerah yang jernih diukur (merupakan daerah hambatan pertumbuhan bakteri) (Astuti, 2015; Ahmad, 2015).

\subsubsection{Analisis Data}


Journal of Pharmaceutical and Health Research

Vol 2, No 2, Juni 2021, pp. 28-33

ISSN 2721-0715 (media online)

DOI 10.47065/jharma.v2i2.841

Data yang diperoleh dalam penelitian ini dianalisis dengan menggunakan aplikasi SPSS One Way ANOVA untuk mengetahui perbedaan masing-masing kelompok perlakuan.

\section{HASIL DAN PEMBAHASAN}

\subsection{Determinasi Tumbuhan}

Hasil determinasi menunjukan bahwa tanaman yang digunakan untuk penelitian benar daun bandotan dan memiliki nama ilmiah Ageratum conyzoides L.

\subsection{Skrining Fitokimia}

Skrining fitokimia dilakukan untuk mengetahui kandungan metabolit sekunder dari suatu tumbuhan atau ekstrak. Hasil skrining fitokimia ekstrak etanol 96\% daun bandotan (Ageratum conyzoides L) dapat dilihat pada tabel 1.

Tabel 1. Hasil Skrining Fitokimia

\begin{tabular}{ccc}
\hline No & Parameter Uji & Hasil Pengujian \\
\hline 1 & Alkaloid & + \\
2 & Flavonoid & + \\
3 & Tanin & + \\
4 & saponin & + \\
5 & Fenolik & + \\
6 & Steroid dan & + \\
& Triterpenoid & + \\
7 & Glikosida & + \\
\hline
\end{tabular}

Berdasarkan hasil skrining fitokimia dengan pereaksi warna tampak bahwa terdapat perbedaan kemampuan pelarut dalam menarik senyawa-senyawa metabolit sekunder yang terkandung pada sampel. Hasil menunjukkan bahwa pelarut etanol, yang merupakan pelarut paling polar yang umum digunakan dalam ekstraksi, lebih banyak menarik senyawa metabolit sekunder yang terkandung daun bandotan (Ageratum conyzoides $L$ ) yang terdapat pada Tabel 1 . Dari hasil pengamatan menunjukan bahwa ekstrak etanol $96 \%$ daun bandotan mengandung senyawa alkaloid, flavonoid, tanin, saponin, fenolik, steroid dan triterpenoid, dan glikosa yang berfungsi sebagai zat aktif yang memiliki aktivitas antibakteri (Ismiyati \& Mardiyaningsih, 2015).

\subsection{Ekstraksi}

Proses ekstraksi pada penelitian ini menggunakan pelarut polar etanol $96 \%$ untuk mengekstrak bahan aktif yang bersifat polar. Hasil maserasi dengan pelarut etanol 96\% diperoleh ekstrak kental yang didapat sebanyak 154,6 gram dihitung kadar rendemen ekstrak. Rendemen ekstrak dihitung berdasarkan perbandingan berat akhir (berat ekstrak yang dihasilkan) dengan berat awal (berat serbuk simplisia yang digunakan) dikalikan 100\%. Hasil rendemen ekstrak daun bandotan sebesar 7,73\%. Perhitungan rendemen dan hasil ekstraksi dapat dilihat pada Tabel 2.

Tabel 2. Hasil presentasi ekstrasi

\begin{tabular}{ccccc}
\hline \multirow{2}{*}{ Simplisia } & Ekstrak & Berat & Berat Ekstrak & Rendemen \\
& & Simplisia (g) & Kental $(\mathrm{g})$ & $(\%)$ \\
\hline Daun Bandotan & Etanol 96\% & 500 & 154,6 & 7,73 \\
\hline
\end{tabular}

Ekstrak etanol $96 \%$ daun bandotan yang diperoleh selanjutnya dilakukan uji bebas etanol. Uji dilakukan untuk mengetahui apakah ekstrak etanol yang diperoleh bebas kontaminasi etanol atau tidak. Hal ini dikarenakan etanol dapat berperan sebagai antibakteri, sehingga tidak akan menimbulkan positif palsu pada perlakuan sampel (Sumiati, 2014; Kurniawati, 2015). Hasil yang diperoleh menunjukkan tidak adanya bau iodoform dan tidak ada endapan kuning dalam waktu 30 menit (Sumiati, 2014). Hal ini membuktikan bahwa ekstrak tersebut bebas dari etanol.

\subsection{Uji Aktivitas Antibakteri}

Prinsip percobaan uji aktivitas antibakteri dilakukan dengan pemberian ekstrak daun bandotan (Ageratum conyzoides L) terhadap bakteri Streptococcus pyogenes pada media NA dengan konsentrasi 100\%, 50\%, 25\%, 12,5\%, 6,25\%. Penghambatan pertumbuhan tersebut dapat dilihat dengan adanya zona bening yang terbentuk di sekitar kertas cakram yang menandakan tidak adanya bakteri yang tumbuh. Hal tersebut menunjukkan bahwa sampel ekstrak yang digunakan memiliki aktivitas yang dapat menghambat pertumbuhan bakteri (Hudzicki, 2016).

Kontrol positif yang digunakan adalah kloramfenikol 1000 pm. kloramfenikol merupakan antibiotik berspektrum luas terhadap bakteri Gram positif dan Gram negatif pada manusia (Pratiwi, 2008). Kontrol positif ini berfungsi sebagai pembanding diameter hambat terhadap ekstrak daun bandotan (Ageratum conyzoides L) terhadap bakteri uji. Kontrol negatif yang digunakan pada penelitian ini adalah pelarut DMSO 100\% yang diteteskan pada kertas cakram steril. 


\section{Journal of Pharmaceutical and Health Research}

Vol 2, No 2, Juni 2021, pp. 28-33

ISSN 2721-0715 (media online)

DOI 10.47065/jharma.v2i2.841

Hasil penelitian uji aktivitas antibakteri ekstrak daun bandotan (Ageratum conyzoides L) terhadap Streptococcus pyogenes tercantum pada Tabel 3. Hasil menunjukkan bahwa kelima konsentrasi ekstrak daun bandotan (Ageratum conyzoides $L$ ) yang diujikan memiliki aktivitas penghambatan terhadap Streptococcus pyogenes. Hasil juga menunjukkan bahwa semakin besar konsentrasi ekstrak, maka semakin besar pula diameter daya hambat yang ditunjukkan terhadap bakteri Streptococcus pyogenes. Hal ini membuktikan bahwa semakin banyak senyawa aktif yang terkandung dalam ekstrak tersebut (Lingga, dkk., 2016).

Tabel 3. Rata-Rata Diameter Daya Hambat (DDH) Ekstrak Daun Bandotan (Ageratum conyzoides L)

\begin{tabular}{lccccccc}
\hline \multirow{2}{*}{ Zona Bening } & \multicolumn{3}{c}{ Konsentrasi (mm) } & \multicolumn{3}{c}{ Kontrol (mm) } \\
& & & \multicolumn{4}{c}{ Kloramfenikol } & DMSO2\% \\
& $100 \%$ & $50 \%$ & $25 \%$ & $12,5 \%$ & $6,5 \%$ & $(+)$ & $(-)$ \\
\hline Perlakuan I & 14,87 & 13,71 & 13,31 & 12,71 & 11,92 & 15,10 & 6 \\
Perlakuan II & 14,35 & 13,81 & 13,81 & 12,49 & 11,50 & 14,95 & 6 \\
Perlakuan III & 14,36 & 14,10 & 12,98 & 11,95 & 11,82 & 15,92 & 6 \\
Rata-Rata & 14,52 & 13,87 & 13,38 & 12,38 & 11,75 & 15,33 & 6 \\
\hline
\end{tabular}

Ekstrak etanol 96\% daun bandotan pada konsentrasi 100\% memiliki zona bening paling besar, berdasarkan hasil tersebut dapat disimpulkan semakin tinggi konsentrasi semakin besar aktivitas antibakteri dan zona bening yang terbentuk.

Terbentuknya daya hambat diduga karena adanya senyawa aktif yang terkandung dalam daun bandotan. Daun bandotan mengandung beberapa senyawa yang berfungsi sebagai antibakteri, diantaranya adalah flavonoid, tanin, dan saponin sehingga dapat memberikan diameter daya hambat sebagai aktivitas penghambatan terhadap pertumbuhan Streptococcus pyogenes. Flavonoid memiliki aktivitas untuk menghambat pertumbuhan bakteri dengan merusak membran sel (Gorniak et al., 2019). Tanin merupakan senyawa polifenol yang bekerja dengan mengganggu kerja DNA gyrase (Khameneh et al., 2019). Saponin dapat melarutkan lipid pada membran sel bakteri (lipoprotein), akibatnya dapat menurunkan tegangan permukaan lipid, fungsi sel bakteri menjadi tidak normal dan sel bakteri lisis sehingga bakteri akan mati (Syafriana et al., 2019). Berdasarkan hal-hal tersebut, maka dapat disimpulkan bahwa Daun Bandotan (Ageratum conyzoides $L$ ) memiliki efek antibakteri terhadap Streptococcus pyogenes.

\subsection{Analisis Data}

Zona bening yang diperoleh pada uji aktivitas antibakteri terhadap Streptococcus pyogenes selanjutnya diolah data statistik menggunakan Uji One Way ANOVA (Analysis of Variant) karena pada penelitian ini terdapat lebih dari 2 perlakuan dengan $\mathrm{p}>0,05$. Pengujian ini menggunakan program SPSS 24. Sebelum melakukan uji ANOVA, dilakukan uji normalitas untuk mengetahui data tersebut normal atau tidak dengan syarat p >0,05. Hasil uji normalitas One-Sample Kolmogorov-Smirnov pada data Streptococcus pyogenes adalah $\mathrm{p}=0,917$ yang berarti data tersebut terdistribusi normal karena $\mathrm{p}>0,05$.

Selanjutnya dilakukan uji homogenitas varians untuk menentukan hipotesis dan kaidah penerimaan atau penolakan. Pada pengujian ini diperoleh data yaitu $\mathrm{p}=0,06$. Dari hasil tersebut dapat dinyatakan data sudah homogen karena $\mathrm{p}>0,05$. Kemudian dilanjutkan dengan One Way Anova bertujuan untuk mengetahui ada tidaknya perbedaan rata-rata zona bening pada masing-masing konsentrasi ekstrak etanol 96\% daun bandotan. Dari uji ANOVA terlihat nilai signifikan $\mathrm{p}=0,000$ yang berarti $<0,05$, hal ini menunjukan bahwa ada perbedaan rata-rata pada setiap konsentrasi. Karena terdapat perbedaan rata-rata pada tiap konsentrasi larutan uji.

Selanjutnya dilakukan uji Post-Hoc, yaitu Tukey. Uji ini digunakan untuk mengetahui manakah diantara kelompok yang memiliki nilai signifikan paling berbeda, pada larutan uji kontrol positif baik dibandingkan dengan kontrol negatif, konsentrasi $6,25 \%, 12,5 \%, 25 \%$, dan $50 \%$ berbeda secara signifikan dengan masing-masing koefisien secara urut yaitu 9,$04667 ; 3,30000 ; 2,66333 ; 1,68000 ; 1,17333$. Perbedaan tersebut ditunjukkan oleh bilangan signifikansi yang diperoleh (Sig.) sebesar 0,000; 0,000; 0,000; 0,000 dan 0,002 yang mana jauh lebih kecil dari taraf signifikansi yang ditetapkan, yakni 0,05. Dari data tersebut dapat disimpulkan pada tiap konsentrasi baik pada konsentrasi larutan uji, kontrol positif dan kontrol negatif terlihat adanya perbedaan mean yang signifikan atau bermakna.

\section{KESIMPULAN}

Berdasarkan uji aktivitas antibakteri terhadap Streptococcus pyogenes dengan konsentrasi 100\%, 50\%, 25\%, 12,5\%, $6,25 \%$ menunjukkan adanya zona bening pada konsentrasi berturut-turut dengan rata-rata sebesar 14,52 mm; $13,87 \mathrm{~mm}$; $13,38 \mathrm{~mm} ; 12,38 \mathrm{~mm} ; 11,75 \mathrm{~mm} ; 15,33 \mathrm{~mm}$. Berdasarkan hasil penelitian dapat disimpulkan bahwa berdasarkan hasil penelitian menunjukkan bahwa perbedaan konsentrasi ekstrak etanol 96\% daun bandotan (Ageratum conyzoides L) dalam formula sediaan mempunyai aktivitas antibakteri terhadap bakteri Streptococcus pyogenes.

\section{DAFTAR PUSTAKA}




\section{Journal of Pharmaceutical and Health Research}

Vol 2, No 2, Juni 2021, pp. 28-33

ISSN 2721-0715 (media online)

DOI 10.47065/jharma.v2i2.841

Ahmad, I. (2015). Aktivitas antibakteri dari fraksi daun bandotan (Ageratum conyzoides L.) secara kromatografi lapis tipis bioautografi. Journal of Tropical Pharmacy and Chemistry, 3(1), 29-36.

Arifin, H., Oktavia, S., \& Chania, S. (2019). Efek Toksisitas Sub Akut Fraksinasi Air Ekstrak Etanol Daun Bandotan (Ageratum Conyzoides (L.) L.) Terhadap Beberapa Parameter Darah Mencit Putih Jantan. Jurnal Farmasi Higea, 11(2), 166-174.

Astuti, H. (2015). Uji aktivitas antibakteri ekstrak etanol dan ekstrak air daun bandotan (Ageratum conyzoides, L.) terhadap Staphylococcus aureus dan Escherichia coli. Majalah Farmaseutik, 11(1), 290-293.

Brooks, G.F., Carrol, C.K., Butel, S.J., Morse, A.M., dan Mietzner, A.T. (2013). Jawetz, Melnick, \& Adelberg Medical Microbiology. The McGraw-Hill Companies. hal : 211-216.

Gorniak, I., Bartoszewski, R., \& Kroliczewski, J. (2019). Comprehensive review of antimicrobial activities of plant flavonoids. Phytochem Rev., 18, 241-272

Hingkua, S. S., Julaeha, E., \& Kurnia, D. (2013). Senyawa triterpenoid dari batang tumbuhan mangrove Avicennia marina yang beraktivitas antibakteri. In Seminar Nasional Sains dan Teknologi Nuklir (pp. 226-230).

Hudzicki, J. (2016). Kirby-Bauer disk diffusion susceptibility test protocol. American Society for Microbiology, 1-23

Ismiyati, N., \& Mardiyaningsing, A. (2015). Aktivitas Sitotoksik Ekstrak Etanolik dan Fraksi dari Ekstrak Etanolik Daun Pandan (Pandanus amaryllifolius roxb) Terhadap Sel Kanker Payudara MCF-7. In Prosiding Seminar Nasional \& Internasional.

Khameneh, B., Iranshahy, M., Soheili, V., \& Bazzaz, B.S.F. (2019). Review on plant antimicrobials: A mechanistic viewpoint. Antimicrobial Resistance and Infection Control, 8, 1-28.

Kurniawati, E. (2015). Daya antibakteri ekstrak etanol tunas bambu apus terhadap bakteri Escherichia coli dan Staphylococcus aureus secara in vitro. Jurnal Wiyata, 2(2), 193-199.

Laoli, N. S. (2018). Uji Aktivitas Antibakteri Ekstrak Etanol Daun Bandotan (Ageratum conyzoides L.) Terhadap Bakteri Bacillus substilis dan Proteus vulgaris. SKRIPSI. Universitas Sumatera Utara.

Lau, S. H. A., Herman, H., \& Rahmat, M. (2019). Studi Perbandingan Tingkat Pengetahuan Masyarakat Tentang Obat Herbal Dan Obat Sintetik Di Campagayya Kelurahan Panaikang Kota Makassar. Jurnal Farmasi Sandi Karsa, 5(1), 33-37.

Lingga, A.R., Pato, U., \& Rossi, E. (2016). Uji antibakteri ekstrak batang kecombrang (Nicolaia speciosa Horan) terhadap Staphylococcus aureus dan Escherichia coli. JOM Faperta, 3(1), 1-15.

Mengkido, M., Lambui, O., \& Harso, W. (2019). Uji daya hambat ekstrak daun bandotan (Ageratum conyzoides L.) terhadap pertumbuhan bakteri Staphylococcus aureus. Biocelebes, 13(2), 121-130.

Mentari, I. A., Wirnawati, W., \& Putri, M. R. (2020). Karakterisasi Simplisia dan Ekstrak Daun Bandotan (Ageratum conyzoides L) sebagai Kandidat Obat Karies Gigi. Jurnal Ilmiah Ibnu Sina, 5(1), 1-9.

Mulyani, Y., Febiani, L., \& Yuniarto, A. (2021). REVIEW ARTIKEL TANAMAN BANDOTAN (Ageratum conyzoides Linn) SEBAGAI ANTIBAKTERI, ANTIOKSIDAN DAN ANTIINFLAMASI. Jurnal Farmasi dan Sains Vol, 5(1).

Munira, M., Rodisa, F., \& Nasir, M. (2020). Uji antibakteri kombinasi ekstrak daun Biduri (Calotropis gigantea L.) dan daun Bandotan (Ageratum conyzoides L.). Jurnal SAGO Gizi dan Kesehatan, 1(2), 165-171.

Pratiwi, S.T. (2008). Mikrobiologi Farmasi. Penerbit Erlangga. Jakarta, Hal 154-160, 188-190

Radji, Maksum., dan Manurung. (2011). Buku Ajar Mikrobiologi Panduan Mahasiswa Farmasi Kedokteran. Jakarta. Buku Kedokteran EGC. hal : 99

Safrida, Y.D., Rahmah, R. (2021). Uji Hambat Ekstrak Etanol Daun Bandotan (Ageratum conyzoides Linn) terhadap Pertumbuhan Bakteri Escherichia coli. Jurnal Sains dan Kesehatan Darussalam (Akafarma-Aceh). 1(1), 17-23.

Sidoretno, W. M., \& Rz, I. O. (2018). Edukasi Bahaya Bahan Kimia Obat yang Terdapat Didalam Obat Tradisional. Jurnal Pengabdian Masyarakat Multidisiplin, 1(2), 177-123.

Sugara, T. H., Irawadi, T. T., Suprapto, I. H., \& Hanafi, M. (2016). Uji Aktivitas Antibakteri Fraksi Etil Asetat Daun Tanaman Bandotan (Ageratum conyzoides L). Jurnal Ilmiah Ibnu Sina, 1(1), 88-96.

Suhartati, R. (2018). Aktivitas antibakteri ekstrak etanol kulit buah naga merah (Hylocereus polyrhizus) terhadap bakteri Streptococcus pyogenes. Jurnal Kesehatan Bakti Tunas Husada: Jurnal Ilmu-ilmu Keperawatan, Analis Kesehatan dan Farmasi, 17(2), 513518 .

Sumiati, E. (2014). Uji aktivitas antibakteri ekstrak kloroform dan ekstrak etanol biji bidara laut (Strychnos ligustrina $\mathrm{Bl}$ ) terhadap Staphylococcus aureus ATCC 25923 dan Salmonella thypi. Biogenesis, 2(1), 1-10.

Syafriana, V., Ningsih, W., \& Wahidin. (2019, Juni). Uji aktivitas antibakteri metanol daun hijau tanaman pucuk merah (Syzygium myrtifolium Walp.) terhadap Pseudomonas aeruginosa dan Staphylococcus epidermidis [oral presentation]. Prosiding Seminar Nasional Pemanfaatan Bahan Alam sebagai Obat, Kosmetik dan Pangan Fungsional, Jakarta, Fakultas Farmasi Universitas Pancasila.

Syafriana, V., Hamida, F., Damayanti, R., \& Nanda, E. V. (2020). Aktivitas antibakteri ekstrak biji anggur (Vitis vinifera L.) terhadap Streptococcus pyogenes. Sainstech Farma, 13(1), 40-44.

Wijaya, I., \& Ulpah, S. (2018). PEMANFAATAN BABADOTAN (Ageratum conyzoides L) UNTUK MENGENDALIKAN HAMA KUTU DAUN PADA TANAMAN CABAI RAWIT (Capsicum frustescent L.). DINAMIKA PERTANIAN, 34(2), 151-162.

Yassir, M., \& Asnah, A. (2017). Pemanfaatan Jenis Tumbuhan Obat Tradisional Di Desa Batu Hamparan Kabupaten Aceh Tenggara. JESBIO: Jurnal Edukasi dan Sains Biologi, 6(2). 